\title{
Physical Properties of Agbabu and Yegbata Bitumen in Nigeria
}

\author{
Shadrach Olise Ogiriki*, Jennifer Oyindamola Adepoju, Adeyinka Sikiru Yusuff and Victor \\ Anochie \\ Department of Chemical and Petroleum Enigeering, Afe Babalola Univetsity, Km 8.5, Afe \\ Babalola Way, P.M.B. 5454 Ado-Ekiti, Nigeria
}

\begin{abstract}
This experimental work evaluates the physical properties of Abagbu and Yegbata bitumen from Nigeria with comparison with that of Canada being the world largest producer of crude oil from bitumen. This study employed the American Society for Testing and Materials (ASTM) methods in conducting laboratory experiments in order to determine the viscosity, specific gravity, API (American Petroleum Institute) gravity, pour point and flash point. A Gas Chromatograph (GC) was used to determine the hydrocarbon content of the bitumen samples. Test results showed that the specific gravity for the bitumen sampleswas 1.01 with a $0.9962{ }^{\circ}$ API for Yegbata, while that of Agbabu bitumen sample was 8.599 specific gravity and $10.54{ }^{\circ}$ API. Kinematic viscosity was $1.0 \times 10^{2}$ to $3.3 \times 10^{4}$ and $1.6 \times 10^{3}$ to $5.6 \times 10^{4}$, flash point of $288^{\circ} \mathrm{C}$ and $282^{\circ} \mathrm{C}$ and pour point of $44^{\circ} \mathrm{C}$ and $47^{\circ} \mathrm{C}$. The gas chromatography analysis showed that the samples contained $46.35 \%$ and $7.59 \%$ saturates, $21.63 \%$ and $64.39 \%$ aromatics and $32.03 \%$ and $28.01 \%$ resins for Agbabu and Yegbata respectively. In comparison with Athabasca bitumen, the results were similar. The assessment and comparison of these properties with the properties of bitumen from Athabasca in Canada reveals that any surface or subsurface crude bitumen gotten from Agbabu and Yegbata in Ondo State, Nigeria can be exploited using similar technologies, if not the same as the technologies being used in Athabasca, Canada
\end{abstract}

Keywords: Tar sand, Bitumen, Agbabu, Yegbata, Nigerian Bitumen, Nigeria, Physical properties,

\section{Introduction}

Bitumen is a mixture of organic liquids that are highly viscous, black, sticky, entirely soluble in carbon disulphide, and composed primarily of highly condensed polycyclic aromatic hydrocarbons. Bitumen in its natural form is characterised by high viscosity, high density (low API gravity: which is the inverse of crude oil density relative to that of water. This is used to compare crude oil densities of crude oils), and high concentrations of nitrogen, oxygen, sulphur, and heavy metals [1]. Bitumen can also be described as a sticky, tar-like form of petroleum which is so thick and heavy that it must be heated or diluted before it will flow. Bitumen is found in tar sands, which are also a combination of clay, sand and water [2], it is extracted from these tar sands and then refined into oil. At room temperature, it has a consistency much like cold molasses (thick dark syrup produced by boiling down juice from sugar cane; especially during sugar refining). Refined bitumen is the residual (bottom) fraction obtained by fractional distillation of crude oil. It is the heaviest fraction and the one with the highest boiling point, at $525^{\circ} \mathrm{C}\left(977^{\circ} \mathrm{F}\right)$. It can also be refined to produce commercial products such

\footnotetext{
* Corresponding author.

E-mail address: shadrachogiriki@abuad.edu.ng

Manuscript History:

Received 6 September, 2017, Revised 19 March, 2018, Accepted 23 March, 2018, Published 31 March, 2018
}

e-ISSN: 2289-7771

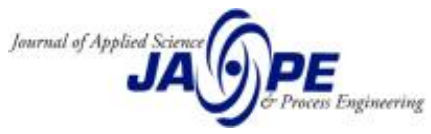


as gasoline, fuel oil and asphalt. Bitumen and extra-heavy oils are unconventional crude oils that generally require additional processing to extract, transport, and refine into petroleum products than conventional oils [3]. These additional steps typically incur additional costs - including investment costs as well as environmental and social costs [3]. As conventional oil reserves decline, oil and gas companies are increasingly turning their attention towards unconventional oils to meet rising global demand for petroleum products.

Nigeria has an estimated 38 billion barrels of extra-heavy oil and bitumen reserves [3]. While this amount is significant, and roughly equivalent to its present conventional oil reserves, this amount is much smaller than Canada's 2.4 trillion barrels and Venezuela's 2.1 trillion barrels [3]. Nigeria has the sixth largest bitumen deposit in the world with most of the reserve found in Ondo state [3]. The discovery of the Nigerian Bitumen dates back to the early 18th century. The history of bitumen in Nigeria goes as far back as 1903 [4]. The Nigerian bitumen reserves are found in Lagos, Ogun, Ondo and Edo States. Nigeria being one of the largest producers of crude oil however, the mid-stream sector of the oil and gas sector has made her heavily dependent on importing refined petroleum products and this includes bitumen. Currently, Nigeria's annual consumption of bitumen is a little over 500,000 metric tonnes and the market has been quite stable and increasing due to the epileptic performance of the Kaduna refinery which is the only refinery in the country that produces bitumen at the moment.

Three potential methods of bitumen extraction in Nigeria are:

1. Small-scale surface mining

2. Large-scale surface mining, and

3. Thermal extraction method.

The depth of bitumen below the surface determines which extraction type is possible. Both thermal extraction and large - scale surface mining operations are most likely to extract bitumen for upgrading into synthetic crude oil and/or other petroleum products. Bitumen from small-scale surface mining is likely to only be economical to use for paving roads. The three types of extraction methods stated above may have environmental impacts [3]. These impacts vary widely. While surface mining completely transforms the entire surface of the mining area, thermal sub-surface extraction renders changes to the underground. Most environmental impacts will directly affect land-based livelihoods throughout Nigeria's bitumen belt. For each type of extraction, impacts are ranked from 'HIGH', or large-scale, significant impact to 'LOW', or smaller- scale, moderate impact [3].

Thermal extraction involves the drilling of wells to extract the bitumen from the subsurface. (75-400m and further below the surface) [3]. Canadian projects currently use two types of thermal extraction methods:

1. Cyclic Steam Stimulation (CSS), and

2. Steam Assisted Gravity Drainage (SAGD).

The existence of bitumen in Nigeria dates back to its discovery in the early 18th century. However, due to the discovery of conventional crude oil in commercial quantities in the early 1960's among other factors, bitumen has since its discovery in Nigeria, remained untapped. Crude oil is a major source of energy in Nigeria and the world in general. For the past three decades, crude oil has been a major source of revenue and foreign exchange for the Nigerian economy. In the recent years, there has been a drastic drop in the price of a barrel of Brent crude to as low as $\$ 27.67$ and $\$ 28.36$ for US crude. This occurrence among others has shun more light to the bitumen industry in Nigeria. The techniques involved in extracting bitumen from the subsurface are now being evaluated and compared.

One major problem associated with extracting bitumen from subsurface formations is that it requires more advanced methods than those used to extract conventional oils. This is due to the high viscosity of bitumen. For this reason, coupled with other properties of the bitumen, selecting the most effective recovery method that would have little or no negative impact on the environment has been a major challenge in the bitumen industry. 
This research evaluates the physical properties of Nigerian bitumen through laboratory tests (some of which include viscosity tests, specific gravity tests, pour point test, among others) and thus infer the best thermal recovery process for the bitumen deposits.

This study is limited to Nigerian bitumen deposits. Samples were collected from Ondo state in the south-western part of Nigeria. Experiments were conducted with this bitumen samples. The results and inferences made are limited to these samples.

\section{Materials and Methods}

\subsection{Sample Preparation}

The tar sand samples were obtained from two (2) different locations in Ondo State. Both samples were collected from locations within latitude $6^{\circ} 38^{\prime} \mathrm{N}$ and $6^{\circ} 39^{\prime} \mathrm{N}$ and longitude $4^{\circ} 55^{\circ} \mathrm{E}$ and $4^{\circ} 34^{\circ} \mathrm{E}$ of the Greenwich Meridian [5]. Sample A was obtained from Agbabu, situated in Odigbo, Ondo State, Nigeria lying on the coordinates $6^{\circ} 35^{\prime} 0^{\prime \prime}$ North, $4^{\circ} 50^{\prime} 0^{\prime \prime}$ East. Sample B was obtained from Yegbata, Ondo State, Nigeria.

The samples were collected from the surface of the ground from the vast tar sands outcrops and sealed in polythene bags to prevent the oxidation of the hydrocarbons before being taken to the laboratory.

The bitumen samples were extracted from the tar sands using the soxhlet extraction process. Experiments were carried out on the extracted bitumen samples to determine their physical properties. The physical properties determined in the laboratory include:
1. Density
2. Viscosity
3. Flash Point
4. Pour Point
5. Hydrocarbon Content

The Brookfield rheometer was used to determine the viscosity of the bitumen. This rheometers operate by rotating a spindle in the sample. Viscosity is determined by measuring resistance to this rotational force [7], while the flash point of the bitumen was determined with the 'open-cup' test method using the Cloveland open cup apparatus.

For the purpose of this study, the ASTM D97, Standard Test Method for Pour Point of Crude Oils also known as the Manual Method was used to determine the pour point of the bitumen sample as shown in Figure 3-5 below.

\subsection{Bitumen Extraction}

The obtained tar sand samples were in a solid compact form. As it was difficult to work with the tar sand samples in this form, the samples were crushed into powder and the bitumen was extracted from the tar sand using the soxhlet apparatus, as shown in Figure 1, with toluene as the extraction solvent.

The Soxhlet extractor, invented in 1879 by Franz von Soxhlet, was initially used to extract lipids from solid materials. The extractor only works when the solute being extracted has limited solubility in the solvent in which it is dissolved. This means that the Soxhlet extractor cannot be used to extract ionic salts from polar solvents such as water, because the solubility limit of such salts in water is extremely high. A Soxhlet Extractor has three main sections: A percolator (boiler and reflux) which circulates the solvent, a thimble (usually made of thick filter paper) which retains the solid to be laved, and a siphon mechanism, which periodically empties the thimble. 
The soxhlet apparatus operates with the evaporation of gas formed from the heating of the solvent in the flat bottom flask into the condenser and the condensation of this gas back to liquid into the core in the long neck flask (reflux) where it cleans the oil from the pores of the core sample. The process is a continuous cycle that is repeated until the solvent going back into the flat bottom flask appears as a clear liquid.

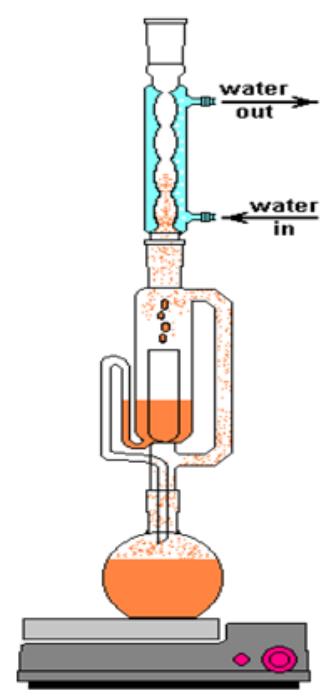

Figure 1. A soxhlet extraction mechanism.

\subsection{Density}

The density test was carried out using a pycnometer and a weighing balance. The value obtained for the density was then used to estimate the specific gravity and API gravity using standard equations.

Density determination by pycnometer is a very precise method. It uses a working liquid with well-known density, such as water to determine the unknown density of another fluid. For this experiment, distilled water was used as the reference liquid. Pycnometer, a precision piece of glassware consists of two portions: a bottle and a stopper. The bottom portion is a small bottle with a volume which may be accurately determined from the mass of water it holds at a particular temperature. The stopper is a capillary tube with a ground glass (frosted) bottom that fits snuggly into the ground glass (frosted) neck of the bottle [6]. The pycnometer is used in ISO standard: ISO 11831:2004, and ASTM standard: ASTM D854. Figure 2 shows the pycnometer being used to determine the density of the bitumen.

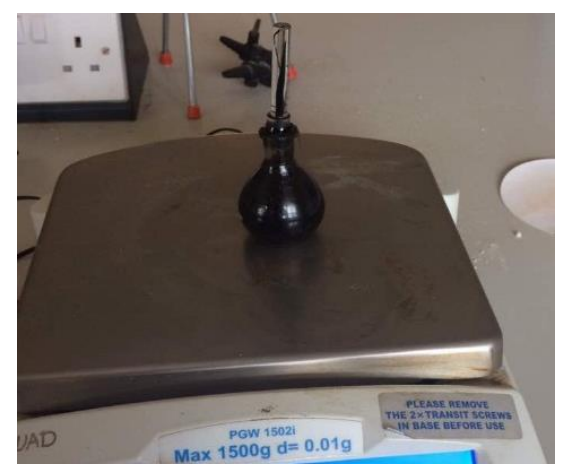

Figure 2. A pycnometer on a weighing balance. 


\subsubsection{Calculations.}

The following equations were used to calculate various variables for this study.

Weight of water, $m_{\mathrm{H}_{2} \mathrm{O}}$ :

$m_{\mathrm{H}_{2} \mathrm{O}}=$ Weight of (Pycnometer - Water - Empty Pycnometer)

Weight of bitumen sample, $m_{A B}$ :

$m_{A B}=$ Weight of (Pycnometer - Bitumen Sample - Empty Pycnometer)

Volume of pycnometer, $\mathrm{V}_{\text {pyc }}$ :

$V_{p y c}=\frac{m_{H_{2} O}}{\rho_{H_{2} O} \mathrm{O}}$

Since the pynometr was used for both the bitumen sample and water, therefore the volume of bitumen, $V_{p y c}$ is derived from equation (3);

$V_{p y c}=\frac{m_{A B}}{\rho_{A B}}$

Therefore, the density of bitumen sample, $\rho_{\mathrm{AB}}$

$\rho_{A B}=\frac{m_{A B}}{V_{p y c}}$

Specific gravity of bitumen sample, $\gamma_{A B}$ :

$\gamma_{A B}=\frac{\rho_{A B}}{\rho_{H_{2} O}}$

API gravity of bitumen sample, API;

$A P I=\frac{141.5}{\gamma_{A B}}-131.5$

\section{$2.4 \quad$ Hydrocarbon Content}

The organic composition of the bitumen samples was evaluated by a gas chromatograph (GC).The American Heritage Dictionary defines GC as a physical method of separation in which the components to be separated are distributed between two phases, one being a stationary bed of large surface area, and the other a gas that percolates through the stationary bed. When the stationary phase is a solid, the separation process is more precisely called gas solid chromatography. This technique is generally used to separate gases in a gaseous solution. The more common technique (which was used in this experiment) is gas liquid chromatography (GLC) in which the stationary phase is a porous solid covered with an absorbing liquid. GLC is used to separate a wide variety of organic compounds.

The basic requirements for GLC are that the sample be volatile and that it not decompose in the vaporization process. Since the vaporization occurs in an inert atmosphere, decomposition of the sample is generally not a problem.

For the purpose of this research, a GC with a cool on-column injection port and GC oven cooling fan domiciled in the Department of Chemical and Petroleum Engineering Chemical Analysis Laboratory, Afe Babalola University was used to analize the samples. The GC is automated as the 
results obtained were in graphics as shown in Figure 3 and Figure 4. The GC parameters are listed in Table 1.

Table 1. GC parameter setting

\begin{tabular}{cccc}
\hline \multicolumn{2}{c}{ Column: Agilent 19091J - 413: 3516. 15684 } \\
\hline $\mathbf{S} / \mathbf{N}$ & Parameter & Unit & Setting \\
$\mathbf{1}$ & Inlet Temperature & ${ }^{\circ} \mathrm{C}$ & $45^{\circ} \mathrm{C}$ \\
$\mathbf{2}$ & Max Temperature & ${ }^{\circ} \mathrm{C}$ & $300^{\circ} \mathrm{C}$ \\
$\mathbf{3}$ & Oven Temperature & ${ }^{\circ} \mathrm{C} / \mathrm{min}$ & $45^{\circ} \mathrm{C}$ initial temperature hold for $2 \mathrm{~min}$ \\
& Program & & then $0.5^{\circ} \mathrm{C} / \mathrm{min}$ to $58^{\circ} \mathrm{C}$ hold for $0 \mathrm{~min}$, \\
& & & then $1.5^{\circ} \mathrm{C} / \mathrm{min}$ to $160^{\circ} \mathrm{C}$ hold for $0 \mathrm{~min}$ \\
$\mathbf{4}$ & Total Run Time & min & $96 \mathrm{mins}$ \\
$\mathbf{5}$ & Carrier Gas Used & & Helium $\left(\mathrm{H}_{\mathrm{e}}\right)$ \\
$\mathbf{6}$ & Carrier Flow & $\mathrm{mL} / \mathrm{min}$ & $1.504 \mathrm{~mL} / \mathrm{min}$ \\
$\mathbf{7}$ & Solvent Used & & Phenyl Methyl Siloxan \\
$\mathbf{8}$ & Injection Volume & $\mu \mathrm{L}$ & $1.0 \mu \mathrm{L}$ \\
$\mathbf{9}$ & FID Temperature & & OFF \\
$\mathbf{1 0}$ & Hold-up Time & Min & \\
$\mathbf{1 1}$ & Injection Mode & & Split \\
\hline
\end{tabular}

\section{Results}

\subsection{Density}

For the experiments carried out to determine the density of the bitumen samples, the following results were obtained:

Table 2. Pycnometer readings for Agbabu bitumen sample

\begin{tabular}{lll}
\hline $\mathbf{S} / \mathbf{N}$ & Description & Value \\
\hline $\mathbf{1}$ & Reference Temperature $\left({ }^{\circ} \mathrm{C}\right)$ & $25^{\circ} \mathrm{C}$ \\
$\mathbf{2}$ & Weight of Empty Pycnometer & $26.02 \mathrm{~g}$ \\
$\mathbf{3}$ & Weight of Pycnometer + Distilled Water & $51.93 \mathrm{~g}$ \\
$\mathbf{4}$ & Weight of Pycnometer + Bitumen Sample & $52.23 \mathrm{~g}$ \\
\hline
\end{tabular}


Table 3. Pycnometer readings for Yegbata bitumen sample

\begin{tabular}{lll}
\hline $\mathbf{S} / \mathbf{N}$ & Description & Value \\
\hline $\mathbf{1}$ & Reference Temperature $\left({ }^{\circ} \mathrm{C}\right)$ & $25^{\circ} \mathrm{C}$ \\
$\mathbf{2}$ & Weight of Empty Pycnometer & $25.70 \mathrm{~g}$ \\
$\mathbf{3}$ & Weight of Pycnometer + Distilled Water & $51.80 \mathrm{~g}$ \\
$\mathbf{4}$ & Weight of Pycnometer + Bitumen Sample & $51.70 \mathrm{~g}$ \\
\hline
\end{tabular}

\subsection{Viscosity}

The viscosity for both bitumen samples were determined at temperatures of $100^{\circ} \mathrm{C}, 80^{\circ} \mathrm{C}, 60^{\circ} \mathrm{C}$ and $40^{\circ} \mathrm{C}$. Table 4 shows the values of the viscosities obtained for each sample at the above stated temperatures.

Table 4. Viscosity values obtained for bitumen samples at various temperatures

\begin{tabular}{llll}
\hline S/N & $\begin{array}{l}\text { Temperature } \\
\left({ }^{\circ} \mathrm{C}\right)\end{array}$ & Viscosity $(\mathbf{c S t})$ & \\
\hline & & Agbabu & Yegbata \\
$\mathbf{1}$ & $100^{\circ} \mathrm{C}$ & 995.5 & 1679.4 \\
$\mathbf{2}$ & $80^{\circ} \mathrm{C}$ & 1365.4 & 2587.5 \\
$\mathbf{3}$ & $60^{\circ} \mathrm{C}$ & 3857.2 & $1.1 \times 10^{4}$ \\
$\mathbf{4}$ & $40^{\circ} \mathrm{C}$ & $3.3 \times 10^{4}$ & $5.6 \times 10^{4}$ \\
\hline
\end{tabular}

\subsection{Flash Point}

The temperatures representing the flash points obtained for both samples are recorded in Table 5.

Table 5. Flash point temperatures for the bitumen samples

\begin{tabular}{lll}
\hline S/N & Flash Point Temperature $\left({ }^{\circ} \mathrm{C}\right)$ \\
\hline $\mathbf{1}$ & Agbabu & Yegbata \\
& $288^{\circ} \mathrm{C}$ & $282^{\circ} \mathrm{C}$ \\
\hline
\end{tabular}




\subsection{Pour Point}

The temperatures representing the pour point obtained for both samples are recorded in Table 6 . The actual pour point was estimated by adding $3^{\circ} \mathrm{C}$ to the obtained pour point as stated in the procedures in appendix A.

Table 6. Pour point temperatures for the bitumen samples

\begin{tabular}{clcc}
\hline S/N & Description & Agbabu & Yegabta \\
\hline $\mathbf{1}$ & Obtained Pour Point $\left({ }^{\circ} \mathrm{C}\right)$ & 41 & 45 \\
$\mathbf{2}$ & Estimated Pour Point $\left({ }^{\circ} \mathrm{C}\right)$ & 44 & 48 \\
\hline
\end{tabular}

\subsection{Gas Chromatography (GC) Analysis}

The results obtained for the GC analysis of the bitumen samples are shown in Table 7 and 8 and the graphs shown in Figure 3 and 4.

Table 7. GC analysis result for Agbabu bitumen

\begin{tabular}{|c|c|c|c|c|c|}
\hline $\begin{array}{l}\text { Peak } \\
\text { Number }\end{array}$ & Compound & $\begin{array}{l}\text { Chemical } \\
\text { Formula }\end{array}$ & $\begin{array}{l}\text { Retention } \\
\text { Time (min) }\end{array}$ & $\%$ Area & $\begin{array}{l}\text { Hydrocarbon } \\
\text { Group }\end{array}$ \\
\hline \multirow[t]{2}{*}{1} & p-Xylene & $\mathrm{C}_{8} \mathrm{H}_{10}$ & 5.362 & 15.38 & Aromatics \\
\hline & o-Xylene & $\mathrm{C}_{8} \mathrm{H}_{10}$ & & & \\
\hline \multirow[t]{2}{*}{2} & o-Xylene & $\mathrm{C}_{6} \mathrm{H}_{6}$ & 6.244 & 3.68 & Aromatics \\
\hline & 1,3-dimethybenzene & $\mathrm{C}_{6} \mathrm{H}_{4}\left(\mathrm{CH}_{3}\right)_{2}$ & & & \\
\hline \multirow[t]{2}{*}{3} & 2-methylpropyl ether & $\mathrm{C}_{7} \mathrm{H}_{16} \mathrm{O}$ & 9.927 & 1.08 & Resins \\
\hline & $\begin{array}{l}\text { 1,4-dihydro-(4- } \\
\text { methylphenyl)methanol }\end{array}$ & & & & \\
\hline \multirow[t]{2}{*}{4} & $\begin{array}{l}\text { Benzene, 1,2,3-trimethyl- } \\
\text { mesitylene- }\end{array}$ & $\mathrm{C}_{6} \mathrm{H}_{3}\left(\mathrm{CH}_{3}\right)_{3}$ & 12.28 & 2.57 & Aromatics \\
\hline & $\begin{array}{l}\text { Benzene, 1,2,4-trimethyl- } \\
\text { mesitylene- }\end{array}$ & $\mathrm{C}_{6} \mathrm{H}_{3}\left(\mathrm{CH}_{3}\right)_{3}$ & & & \\
\hline \multirow[t]{2}{*}{5} & $\begin{array}{l}\text { 3-methyl-1- } \\
\text { adamantaneaneactic acid } \\
\text { pyridine }\end{array}$ & & 24.603 & 8.58 & Resins \\
\hline & Bis(1-methyl) ester & & & & \\
\hline \multirow[t]{2}{*}{6} & $\begin{array}{l}\text { 1,2-dimethyl-5- } \\
\text { nitroadamantane }\end{array}$ & $\mathrm{C}_{12} \mathrm{H}_{19} \mathrm{~N}_{2} \mathrm{O}_{3}$ & 26.236 & 4.62 & Resins \\
\hline & N-Acetyl-L-tyrosinamide & $\mathrm{C}_{11} \mathrm{H}_{14} \mathrm{NO}_{2}$ & & & \\
\hline
\end{tabular}




\begin{tabular}{|c|c|c|c|c|c|}
\hline 7 & $\begin{array}{l}\text { 1-methyl-3- } \\
\text { ethyladamantane }\end{array}$ & $\mathrm{C}_{13} \mathrm{H}_{22}$ & 33.154 & 10.45 & Saturates \\
\hline & Pentamethyl pyride & & & & Resins \\
\hline \multirow[t]{2}{*}{8} & 1,3-dimethyl-adamantane & $\mathrm{C}_{12} \mathrm{H}_{20}$ & 33.836 & 4.5 & Saturates \\
\hline & 1,4-dimethyl-adamantane & $\mathrm{C}_{12} \mathrm{H}_{20}$ & & & \\
\hline \multirow[t]{2}{*}{9} & $\begin{array}{l}\text { 1,3-dimethyl-5-n- } \\
\text { hexyladamantane }\end{array}$ & $\mathrm{C}_{18} \mathrm{H}_{32}$ & 34.831 & 5.01 & Saturates \\
\hline & $\begin{array}{l}\text { 1,3-dimethyl-5-n- } \\
\text { propylladamantane }\end{array}$ & & & & \\
\hline \multirow[t]{2}{*}{10} & 1,3,6-trimethyladamantane & $\mathrm{C}_{13} \mathrm{H}_{22}$ & 37.871 & 10.45 & Saturates \\
\hline & $\begin{array}{l}\text { 1,3-dimethyl-5-n- } \\
\text { propylladamantane }\end{array}$ & & & & \\
\hline \multirow[t]{2}{*}{11} & 1,3,5-trimethyladamantane & $\mathrm{C}_{13} \mathrm{H}_{22}$ & 38.421 & 10.36 & Saturates \\
\hline & $\begin{array}{l}\text { 1,3-dimethyl-5-n- } \\
\text { hexyladamantane-2- } \\
\text { propenal }\end{array}$ & & & & \\
\hline \multirow[t]{2}{*}{12} & $\begin{array}{l}\text { Isophthalic acid, Ethyl 2- } \\
\text { methyloct-5-yn-4-yl ester }\end{array}$ & $\mathrm{C}_{22} \mathrm{H}_{30} \mathrm{O}_{4}$ & 38.99 & 7.29 & Resins \\
\hline & N-dimethylbenzamide & $\mathrm{C}_{9} \mathrm{H}_{11}$ & & & \\
\hline \multirow[t]{2}{*}{13} & $\begin{array}{l}1,3,5- \\
\text { Trimethyladamantane }\end{array}$ & $\mathrm{C}_{13} \mathrm{H}_{22}$ & 42.044 & 16.03 & Saturates \\
\hline & $\begin{array}{l}1,3,4- \\
\text { Trimethyladamantane }\end{array}$ & $\mathrm{C}_{13} \mathrm{H}_{22}$ & & & \\
\hline
\end{tabular}

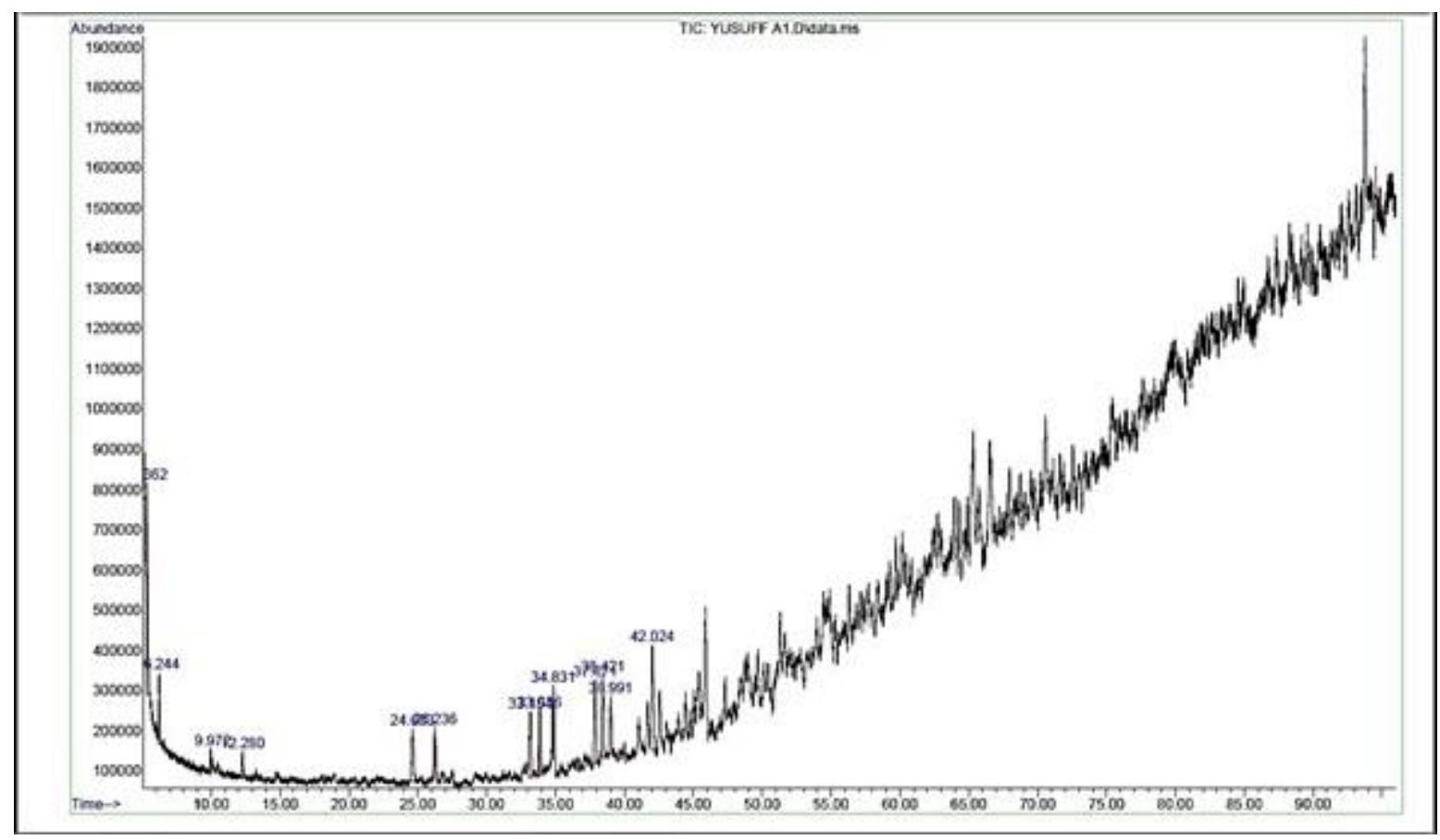

Figure 3. GC analysis graph for Agbabu bitumen. 
Table 8. GC analysis result for Yegbata bitumen

\begin{tabular}{|c|c|c|c|c|c|}
\hline $\begin{array}{l}\text { Peak } \\
\text { Number }\end{array}$ & Compound & $\begin{array}{l}\text { Chemical } \\
\text { Formula }\end{array}$ & $\begin{array}{l}\text { Retention } \\
\text { Time } \\
\text { (min) } \\
\end{array}$ & \%Area & $\begin{array}{l}\text { Hydrocarbon } \\
\text { Group }\end{array}$ \\
\hline \multirow[t]{2}{*}{$\mathbf{1}$} & 1, 3-dimethylbenxane & $\mathrm{C}_{6} \mathrm{H}_{4}\left(\mathrm{CH}_{3}\right)_{2}$ & 5.356 & 27.71 & Aromatics \\
\hline & p-Xylene & $\mathrm{C}_{8} \mathrm{H}_{10}$ & & & \\
\hline \multirow[t]{2}{*}{2} & 1, 3-dimethylbenxane & $\mathrm{C}_{6} \mathrm{H}_{4}\left(\mathrm{CH}_{3}\right)_{2}$ & 6.238 & 6.65 & Aromatics \\
\hline & p-Xylene & $\mathrm{C}_{8} \mathrm{H}_{10}$ & & & \\
\hline 3 & Nonane & $\mathrm{C}_{9} \mathrm{H}_{20}$ & 6.607 & 1.37 & Saturates \\
\hline \multirow[t]{2}{*}{4} & 1-Decene & $\mathrm{C}_{10} \mathrm{H}_{20}$ & 9.328 & 0.99 & Saturates \\
\hline & 1R,2c,3t,4t-Tetramethyl-cyclohexane & $\mathrm{C}_{10} \mathrm{H}_{20}$ & & & \\
\hline 5 & Benzaldehyde & $\mathrm{C}_{7} \mathrm{H}_{6}$ & 9.953 & 25.73 & Resins \\
\hline \multirow[t]{2}{*}{6} & Benzene, 1,2,3-trymethyl- & $\mathrm{C}_{9} \mathrm{H}_{12}$ & 10.448 & 3.77 & Aromatics \\
\hline & Benzene, 1,2,3-trymethyl- & $\mathrm{C}_{9} \mathrm{H}_{12}$ & & & \\
\hline 7 & Benzene, 1-ethyl-3-methyl & $\mathrm{C}_{9} \mathrm{H}_{12}$ & 11.198 & 0.83 & Aromatics \\
\hline \multirow[t]{2}{*}{8} & Mesitylene & $\mathrm{C}_{9} \mathrm{H}_{12}$ & 12.287 & 12.96 & Aromatics \\
\hline & Benzene, 1,2,4-trimethyl- & $\mathrm{C}_{9} \mathrm{H}_{12}$ & & & \\
\hline \multirow[t]{2}{*}{9} & Decane & $\mathrm{C}_{10} \mathrm{H}_{22}$ & 13.25 & 3.95 & Saturates \\
\hline & Nonadecane, 1-chloro & $\mathrm{C}_{19} \mathrm{H}_{39} \mathrm{Cl}$ & & & \\
\hline \multirow[t]{2}{*}{10} & Benzene, 1,2,3-trymethyl- & $\mathrm{C}_{9} \mathrm{H}_{12}$ & 14.733 & 3.61 & Aromatics \\
\hline & Benzene, 1,2,4-trymethyl- & $\mathrm{C}_{9} \mathrm{H}_{12}$ & & & \\
\hline \multirow[t]{3}{*}{11} & Benzene, 1-ethenyl-2- & $\mathrm{C}_{13} \mathrm{H}_{22}$ & 15.871 & 0.93 & Aromatics \\
\hline & Biclo[4.2.0]octa-1,3,5-triene, 7- & $\mathrm{C}_{9} \mathrm{H}_{12}$ & & & \\
\hline & $\begin{array}{l}\text { methyl- } \\
\text { Indane }\end{array}$ & $\mathrm{C}_{9} \mathrm{H}_{12}$ & & & \\
\hline \multirow[t]{3}{*}{12} & o-Cymene & $\mathrm{C}_{10} \mathrm{H}_{14}$ & 18.98 & 3.57 & Aromatics \\
\hline & Benzene, 1-methyl-3-(1-methylethyl)- & $\mathrm{C}_{10} \mathrm{H}_{14}$ & & & \\
\hline & p-Cymene & $\mathrm{C}_{10} \mathrm{H}_{14}$ & & & \\
\hline 13 & $\begin{array}{l}\text { Benzene, 1-ethyl-3,5-dimethyl- } \\
\text { Benzene, -ethyl-1,4-dimethyl- } \\
\text { Benzene, 4-ethyl-1,2-dimethyl- }\end{array}$ & $\begin{array}{l}\mathrm{C}_{10} \mathrm{H}_{14} \\
\mathrm{C}_{10} \mathrm{H}_{14} \\
\mathrm{C}_{10} \mathrm{H}_{14}\end{array}$ & 22.089 & 1.05 & Aromatic \\
\hline \multirow[t]{2}{*}{14} & Benzene, 4-ethyl-1,5-dimethyl & $\mathrm{C}_{10} \mathrm{H}_{14}$ & 26.223 & 1.99 & Aromatics \\
\hline & Benzene, 4-ethyl-1,5-dimethyl & $\mathrm{C}_{10} \mathrm{H}_{14}$ & & & \\
\hline \multirow[t]{3}{*}{15} & Benzene, 1,2,3,4-tetramethyl- & $\mathrm{C}_{10} \mathrm{H}_{14}$ & 26.761 & 1.32 & Aromatics \\
\hline & Benzene, 1-ethyl-3,5-dimethyl- & $\mathrm{C}_{10} \mathrm{H}_{14}$ & & & \\
\hline & Benzene, 1-ethyl-2,3-dimethyl- & $\mathrm{C}_{10} \mathrm{H}_{14}$ & & & \\
\hline
\end{tabular}




\begin{tabular}{|c|c|c|c|c|c|}
\hline \multirow[t]{3}{*}{16} & $\begin{array}{l}\text { c-(3,5-Dimethyladamantan-1-yl) } \\
\text { methylamine }\end{array}$ & $\mathrm{C}_{10} \mathrm{H}_{20}$ & 38.434 & 1.29 & Saturates \\
\hline & $\begin{array}{l}\text { Ethanone, 1-(2,3-dihydro-1,4- } \\
\text { Benzodioxine-6-yl) }\end{array}$ & $\mathrm{C}_{10} \mathrm{H}_{10} \mathrm{O}_{3}$ & & & Resins \\
\hline & $\begin{array}{l}\text { 2-Propenal, 3-(2,6,6-trimethyl-1- } \\
\text { Cyclohexene-1yl)- }\end{array}$ & $\mathrm{C}_{10} \mathrm{H}_{16} \mathrm{O}$ & & & Saturates \\
\hline 17 & $\begin{array}{l}\text { Trans-.beta.lonone } \\
\text { 1,3,5,6-Tetramethylladamantane }\end{array}$ & $\begin{array}{c}\mathrm{C}_{10} \mathrm{H}_{20} \mathrm{O} \\
\mathrm{C}_{14} \mathrm{H}_{24}\end{array}$ & 39.041 & 1.31 & $\begin{array}{l}\text { Resins } \\
\text { Saturates }\end{array}$ \\
\hline & $\begin{array}{l}\text { 2H-1-Benzopyran,3,5,6,8a- } \\
\text { tetrahydro- } \\
\text { 2,5,5,8a-tetramethyl-,trans- }\end{array}$ & $\mathrm{C}_{13} \mathrm{H}_{20} \mathrm{O}$ & & & Resins \\
\hline 18 & $\begin{array}{l}\text { 2-Propenol, 3-(2,6,6-trimethyl-1- } \\
\text { Cyclohexen-1-yl) } \\
\text { 1,3,4,-Trimethyladamantane } \\
\text { 1(3H)-Isobenzofuranone, 3-[2(2,- } \\
\text { Dihydro-1,4-benzodioxin-6-yl)-2- } \\
\text { Oxoethyl] }\end{array}$ & $\mathrm{C}_{13} \mathrm{H}_{22}$ & 42.031 & 0.97 & Aromatics \\
\hline
\end{tabular}

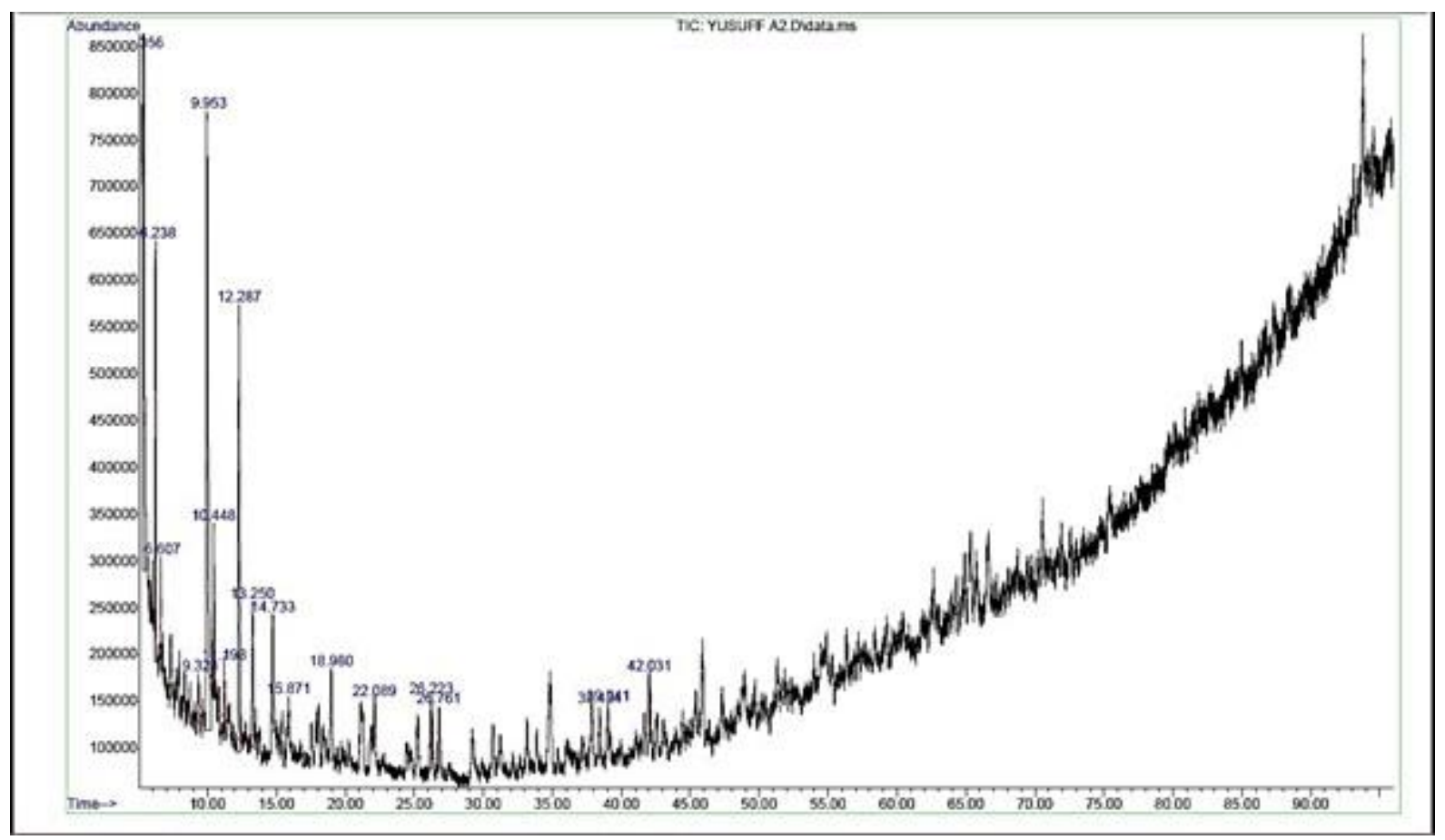

Figure 4. GC analysis graph for Yegabta bitumen

\section{Discussion}

In summary, the results for all the properties of the bitumen samples are highlighted in Table 9. This Table 9 highlights the properties of the bitumen samples from the two locations in Ondo state Nigeria. Applying equation (5), the values obtained for density for both locations are $1.0085 \mathrm{~g} / \mathrm{cm}^{3}$ and $0.9932 \mathrm{~g} / \mathrm{cm}^{3}$ for Agbabu and Yegbata respectively. The result shows that the Agbabu bitumen has a higher density than that of Yegbata,and is also denser than water with density of $0.99705 \mathrm{~g} / \mathrm{cm}^{3}$ at the same temperature of $25^{\circ} \mathrm{C}$. This indicates that the bitumen would sink while the water floats, if both 
samples are mixed at $25^{\circ} \mathrm{C}$. These values compare favourably with the density value of $2.24 \mathrm{~g} / \mathrm{cm}^{3}$ obtained at Agbabu by Akande [8].

The density obtained for both samples were used to estimate the specific gravity of both samples applying equation (6). The values obtained for specific gravity are 1.01 and 0.9962 at $25^{\circ} \mathrm{C} / 25^{\circ} \mathrm{C}$ for Agbabu and Yegbata respectively as shown in Table 9. The specific gravity values compare favourably with the value 0.92 and 0.95 obtained by Guma et al. [9] at two other different locations in Ondo state. It also compares favourably with that of asphalt having 1.013 specific gravity [9]. The specific gravity values were used to estimate, with equation (7), the API gravity values for both locations and values of $8.60^{\circ}$ API and $10.54^{\circ}$ API were obtained for Agbabu and Yegbata respectively. These values fall within the range of API gravity of bitumen defined by Subramanian et al [10] and Lancaster [11].

The temperature values recorded as the flash point for each sample were observed as shown on the Table 5 and Table 9 as $288^{\circ} \mathrm{C}$ and $282^{\circ} \mathrm{C}$ for Agbabu and Yegbata respectively. These flash point values lie within the value range of $245^{\circ} \mathrm{C}$ to $325^{\circ} \mathrm{C}$ as reported by Guma et al. [9] for most bitumen of good grade. The pour point observed for both locations are $44^{\circ} \mathrm{C}$ for Agbabu and $48^{\circ} \mathrm{C}$ for Yegbata respectively. These valeus compare favourably with the vales of $44.70^{\circ} \mathrm{C}$ obtained by Adebiyi et al.[29].

Table 9. Comparison of the physical properties of Agbabu, Yebgata and Athabasca bitumen

\begin{tabular}{|c|c|c|c|c|c|}
\hline \multirow[t]{2}{*}{$\mathbf{S} / \mathbf{N}$} & \multirow{2}{*}{\multicolumn{2}{|c|}{ Properties }} & \multicolumn{3}{|c|}{ Source of Bitumen } \\
\hline & & & Agbabu & Yegbata & $\begin{array}{c}\text { Athabasca Tar Sand } \\
\text { Bitumen Laricina } \\
\text { Energy }^{[27]}\end{array}$ \\
\hline 1 & \multicolumn{2}{|c|}{ Density $\mathrm{g} / \mathrm{cm}^{3}\left(25^{\circ} \mathrm{C}\right)$} & 1.0085 & 0.9932 & 1.0077 \\
\hline 2 & \multicolumn{2}{|c|}{ Specific Gravity $\left(25^{\circ} \mathrm{C} / 25^{\circ} \mathrm{C}\right)$} & 1.01 & 0.9962 & 1.0143 \\
\hline 3 & \multicolumn{2}{|c|}{ API Gravity ${ }^{\circ} \mathrm{API}$} & 8.6 & 10.54 & 8 \\
\hline 4 & \multicolumn{2}{|c|}{ Pour Point $\left({ }^{\circ} \mathrm{C}\right)$} & 44 & 48 & \\
\hline 5 & \multicolumn{2}{|l|}{ Flash Point $\left({ }^{\circ} \mathrm{C}\right)$} & 288 & 282 & \\
\hline 6 & Viscosity (cSt) & $100{ }^{\circ} \mathrm{C}$ & 995.5 & 1679.4 & \\
\hline 7 & & $80{ }^{\circ} \mathrm{C}$ & 1365.41 & 2587.5 & \\
\hline 8 & & $60{ }^{\circ} \mathrm{C}$ & 3857.2 & $1.1 \times 10^{4}$ & \\
\hline 9 & & $40{ }^{\circ} \mathrm{C}$ & $3.3 \times 10^{4}$ & $5.6 \times 10^{4}$ & \\
\hline \multirow[t]{5}{*}{10} & \multicolumn{5}{|c|}{ SARA Composition (wt \%) } \\
\hline & \multicolumn{2}{|l|}{ Saturates } & 46.35 & 7.59 & 14.5 \\
\hline & \multicolumn{2}{|l|}{ Aromatics } & 21.63 & 64.39 & 34.8 \\
\hline & \multicolumn{2}{|l|}{ Resins } & 32.02 & 28.01 & 38 \\
\hline & \multicolumn{2}{|l|}{ Asphaltenes } & & & 12.7 \\
\hline
\end{tabular}

The viscosity of both bitumen samples were observed at various temperatures of $100^{\circ} \mathrm{C}, 60^{\circ} \mathrm{C}$ and $40^{\circ} \mathrm{C}$ as shown in Table 4 . The kinematic viscosity of Agbabu bitumen ranges from $1.0 \times 10^{2} \mathrm{cSt}-$ $3.3 \times 10^{4} \mathrm{cSt}$ as the temperature decreased from $100^{\circ} \mathrm{C}-40^{\circ} \mathrm{C}$. That of Yegbata ranged from $1.6 \times 10^{3} \mathrm{cSt}-$ $5.6 \times 10^{4} \mathrm{cSt}$ as the temperature decreased from $100^{\circ} \mathrm{C}-40^{\circ} \mathrm{C}$. 
The gas chromatography analysis carried out on the samples showed that the samples contained $46.35 \%$ and $7.59 \%$ saturates, $21.63 \%$ and $64.39 \%$ aromatics and $32.03 \%$ and $28.01 \%$ resins for Agbabu and Yegbata respectively.

\subsection{Density}

From Table 9, it can be seen that the density of the bitumen samples of both location (Agbabu and Yegbata), obtained was $1.0085 \mathrm{~g} / \mathrm{cm}^{3}$ and $0.9932 \mathrm{~g} / \mathrm{cm}^{3}$ at $25^{\circ} \mathrm{C}$ respectively, which has a close range. This similarity also falls within a close range with the value of $2.24 \mathrm{~g} / \mathrm{cm}^{3}$ reported by Akande [8]. Comparing this values obtained, with the value of $1.0077 \mathrm{~g} / \mathrm{cm}^{3}$ estimated by Strausz [12], it can be seen that there exist minute differences in the density of the bitumen samples and that of the Athabasca bitumen. Yaser et al. [13] estimated a value of $1.0129 \mathrm{~g} / \mathrm{cm}^{3}$ for the Athabasca bitumen which is also similar to the values obtained for the bitumen for both locations. The Alberta Department of Energy [14] reported values of $1.0136 \mathrm{~g} / \mathrm{cm}^{3}$ and $0.9945 \mathrm{~g} / \mathrm{cm}^{3}$ for the bitumen density at $15^{\circ} \mathrm{c}$ and although at lower temperature the values are close.

\subsection{Specific gravity and API gravity}

The specific gravity obtained for both locations as shown in Table 9 are 1.01 and 0.9962 for Agbabu and Yegbata respectively. The specific gravity of bitumen gives an estimated measure of the amount of lighter hydrocarbons present [15]. Lower specific gravity which corresponds to higher API gravity yields more light fractions during fractional distillation. The values obtained for the samples fall within a close range to each other. These values are also within the range of asphalt standard of 0.9 - 1.013 [15] obtained from the same geological location. This low specific gravity value indicate that the bitumen is of high quality. The specific gravity values compare favourably with the values reported by Guma et al. [9].

Generally, API gravity determines the grade of bitumen and its value increases with decrease in specific gravity. Low API gravity as in the case of the bitumen samples used for the study is associated with either bio-degraded oil or with immature sulphur-rich oils.

From Table 9, the API gravity obtained for both location is 8.60 and 10.54 . These values show a close range of API gravity values with the range of $8.88-10.78^{\circ}$ API which falls within the specifications of Nigerian Association of State Highway and Transportation Officials Standard for Road Materials and also compare favourably with the values $(1.011,0995,1.001){ }^{\circ}$ API obtained by Onajake and Ndubuka [15]for other samples within the same geographic location and $10.060^{\circ} \mathrm{API}$ reported by Adebiyi et al. [16], for Nigerian bitumen. The range of API when compared with those obtained from Athabasca Canada and Cold Lake bitumen samples with API gravity of 8.1 and $10.8^{\circ} \mathrm{API}$ respectively, reported by the Alberta Department of Energy [14], compares favourably.

\subsection{Viscosity}

Viscosity is a measure of internal friction of a liquid to the reluctance of a fluid to flow freely. It therefore indicates the ability of a fluid to flow from the point to another. Kinematic viscosity represents the dynamic viscosity of a fluid per unit density expressed in cSt (Centistoke). Viscosity affects the performance of injection systems [15]. Low viscosity can result in excessive wear in some injection pumps and power loss due to pump and injector leakage. High viscosity fluids on the other hand cause excessive pump resistance or filter damage and higher line pressures [15]. From Table 4, it can be seen that the viscosity for Agbabu bitumen ranges from 995.5 to $3.3 \times 10^{4} \mathrm{cSt}$ as the temperature decreased from $100^{\circ} \mathrm{C}$ to $40^{\circ} \mathrm{C}$. For Yegbata bitumen, the kinematic viscosity values range from $1.6 \times 10^{3}$ to $5.6 \times 10^{4} \mathrm{cSt}$ as the temperature decreased from $100^{\circ} \mathrm{C}$ to $40^{\circ} \mathrm{C}$. These values agree with the 
value range of $4.3 \times 10^{3}$ to $5.6 \times 10^{3} \mathrm{cSt}$ reported by Onajake and Ndubuka [15]. These ranges are higher than the value range of $1.8 \times 10^{4}$ to $1.0 \times 10^{6} \mathrm{cSt}$ reported by Laricina Energy [17].

The values reported by the Alberta Department of Energy [14] are also lower than the value ranges of the Nigerian bitumen, this agrees with Onajake and Ndubuka [15] report that the Nigeria bituminous sands are higher in viscosity than its Athabasca Counterpart. The high viscosities of the bitumen samples are also attributed to its asphaltene content. This high viscosity is advantageous in that the bitumen in its deposits will not flow into the environment to cause pollution in the event of spillage like the conventional oil will do.

\subsection{Flash Point}

Flash point measures only the response of the bitumen sample to heat and flame in or controlled laboratory conditions. The values obtained for the flashpoint of the bitumen samples as shown in Table 5 are $288^{\circ} \mathrm{C}$ and $282^{\circ} \mathrm{C}$ for Agbabu and Yegbata respectively. These values are higher than the $260^{\circ} \mathrm{C}$ and $269^{\circ} \mathrm{C}$ obtained by Guma et al. [9] from samples obtained within the same geographical locations. The values can be seen to fall within the flash point range of 245 to $352^{\circ} \mathrm{C}$ reported by Guma et al. [9] in assessing the overall flammability hazard of samples, the flash point must be considered.

\subsection{Pour Point}

Pour point when used in conjunction with the reservoir temperature gives a better indication of the condition of the oil, in the reservoir than does its viscosity, thus it presents a more accurate assessment of the condition of the oil in the reservoir, being an indicator of the mobility of the oil in the reservoir.

For the sampled bitumen, following the pour point determination procedures stated in Appendix $\mathrm{A}$, the temperature values of $44{ }^{\circ} \mathrm{C}$ and $48{ }^{\circ} \mathrm{Cwere}$ obtained for Agbabu and Yegbata respectively, with the Agbabu bitumen precise, while the Yegbata bitumen is close to the value of $44.70{ }^{\circ} \mathrm{C}$ obtained by Adebiyi et al. [16], indicating the very low mobility on the bitumen fluids at reservoir conditions. It also compares favourably with the pour point temperature range of 50 to $100^{\circ} \mathrm{C}$ identified by Speint. In summary, the pour point is an important consideration because, for efficient production, additional energy must be supplied to the reservoir by a thermal process to increase the reservoir temperature beyond the pour point.

\subsection{GC Analysis}

The results obtained from the gas chromatography are shown in Table 7 and Table 8 for Agbabu and Yegbata respectively. The results provide the hydrocarbons present in the bitumen samples from both locations. It gives the chemical formula of the samples, their retention time, mole\% area and the group of hydrocarbons to which each belongs. From the tables, it can be seen that there exist no long chain asphaltenes compounds in the bitumen samples from both locations, but there exists saturates, aromatics and resins in both samples. The compositions of these hydrocarbons were used for the SARA composition as shown on Table 9. Form Table 9, it can be seen that the bitumen from Agbabu contains $46.35 \%$ saturates, $21.63 \%$ aromatics and $32.03 \%$ resins and that of Yegbata contains $7.59 \%$ saturates, $64.39 \%$ aromatics and $28,01 \%$ resins. 


\section{Conclusions}

It can be concluded that the samples of bitumen from Agbabu and Yegbata in Ondo State of Nigeria has similar physical properties with Canadian Bitumen. The physical properties of the samples bitumen from Agbabu and Yegbata in Nigeria makes it feasible for exploitation. The bitumen is also can be exploited or developed using the techniques employed in the development of Canadian Bitumen.

\section{Acknowledgments}

The authors acknowledge the Management of Afe Babalola University for the use of its facilities for this study.

\section{References}

[1] Attanasi, E.D. and Meyer, R.F. (2010). Natural Bitumen and Extra-Heavy Oil. Survey Energy Resource, $123-150$.

[2] Ebii, C.(2015). Not All That Glitters: Nigeria's Bitumen Story, 1-3.

[3] Milos, C.(2015). Bitumen: Weighing the True Costs, 1-12.

[4] Orire, E. (2009). The Techno-Economics of Bitumen Recovery from Oil and Tar Sands as a Complement to Oil exploration in Nigeria (Doctoral dissertation, North-West University).

[5] Ohenhen, I., Ikiesikimama, S.S. and Olafuyi O.A.(2016). Effect of Temperature on Nigeria Tar Sand Bitumen Viscosity. In: SPE Nigeria Annual International Conference and Exhibition. Lagos: Society of Petroleum Engineers, $1-7$.

[6] Manual of Weighing Applications Part 1.(1999), 1-65.

[7] Carrington, S. and Langridge, J. (2005). Viscometer or Rheometer? Making the Decision. www.iesmat.com. [Last Access]: 01/01/2018.

[8] Akande, J.M. (2007). Analysis of Steam Injection and in situ Combustion Methods of Mining Agbabu Bitumen in Ondo State, Nigeria. Journal of Engineering and Applied Sciences. Vol. 2, No. 10, 1493-1496.

[9] Guma, T.N., Madakson, P.B., Yawas, D.S., Aku, S.Y. (2012). Assessment of Physicochemical Properties of some Bitumens from Nigerian Resources. Nigerian Journal of Basic and Applied Science, Vol. No. 2, $177-81$.

[10] Subramanian, M., Deo, M.D., Hanson, F V.(1996). Compositional Analysis of Bitumen and BitumenDerived Products. J Chromatogr Sci, Vol.34, 20-26.

[11] Lancaster, I.M.(2013). Bitumen \& Bituminous Materials,1-33.

[12] Strausz, O.P., Mojelsky, T.W., and Lown, E.M. (1977). The chemistry of the Alberta oil sand bitumen. Hydrocarbon Research Center, Department of Chemistry, University of Alberta, Edmonton.

[13] Souraki, Y., Ashrafi, M., Karimaie, H. and Torsaeter, O.(2012). Experimental Analyses of Athabasca Bitumen Properties and Field Scale Numerical Simulation Study of Effective Parameters on SAGD Performance. Energy and Environment Research, Vol. 2, No.1, 140-156.

[14] Alberta Department of Energy. Bitumen AssayProgram Aggregate (3), www.energy.alberta.ca. \{last Access]: 01/01/2018.

[15] Onojake, M.C. and Ndubuka, C.O.(2016). Appraisal of the Bulk Properties of Bitumen Samples from Four Deposits in South West, Nigeria, Petroleum \& Coal, Vol. 58, 407-13.

[16] Adebiyi, F.M., Bello, O.O., Sonibare, J.A and Macaulay, S.R,A.(2005). Determination of Sara Constituents of Southwestern Nigerian Tars Sands and their Physical Properties. Engineering Journal of the University of Qatar, Vol. 18, 29-38.

[17] Energy, L. (2013). Heavy Oil. In: Latina American Conference and Exhibition. Mexico: Canadian Heavy Oil Association, 1-17. 